\title{
The Infusion of Notification Design With an Application of Social Media Based on a Internet of Things (IOT)
}

\author{
Rudi Arif Candra ${ }^{1)^{*}}$, Devi Satria Saputra ${ }^{2)}$, Dirja Nur Ilham ${ }^{3)}$, Herry Setiawan ${ }^{4)}$, Hardisal ${ }^{5)}$ \\ ${ }^{122) 334) 5)}$ Politeknik Aceh Selatan, Indonesia \\ ${ }^{1}$ rudi_candra@poltas.ac.id, ${ }^{2}$ devisatria@poltas.ac.id, ${ }^{3)}$ dirja@ poltas.ac.id, ${ }^{4}$ herry@poltas.ac.id , \\ ${ }^{5}$ hardisal@poltas.ac.id
}

Submitted :Sep 4, $2020 \mid$ Accepted : Oct 8, $2020 \mid$ Published : Oct 8, 2020

\begin{abstract}
This study discusses the infusion detection device in a hospital room. This tool is designed to help hospital nurses to cope more quickly to avoid problems due to the infusion. Load cell sensors are used as heavy detectors that send notifications to the nurses through the telegram application that has been installed. The nurse will get a notification message sent to the telegram if the sensor has read the weight. The tool is made using a load cell sensor and NodeMCUWi-FiESP866 which functions to send notification of the results of sensor data input to the Internet of Things (IOT) platform namely Telegram. Nurses need to be connected to the internet network to get notifications on the telegram. Test results show that the time needed to send and receive notifications on Telegram takes about 2-5 seconds. The message will be sent 3 times, first the infusion WARNING is almost exhausted (alert), second the infusion WARNING is almost exhausted (standby) and the infusion WARNING is almost exhausted (please replace). If the infusion is not replaced by the nurse, it will be warned by Buzzer. However, time can be influenced by the available internet network connectivity. However, time can be affected by the available internet network.
\end{abstract}

Keywords: Telegram, Arduino R3, Load Cell, NodeMCU ESP8266

\section{INTRODUCTION}

Intravenous fluids are the administration of a certain amount of fluid into the body, through a needle into a vein. The purpose of giving an infusion to a patient is to replace body fluids and compensate for the amount of electrolytes into the body, it can be given with the intention of adding calories, As a drug, given in large quantities and continuously if it cannot be injected normally, for example anticancer drugs, antibiotics, anesthetics, watersoluble hormones and vitamins. This action is carried out to meet the needs of fluids and electrolytes as well as a treatment and feeding action (NUR, 2016). Research on infusion monitoring has been carried out by(Erdisna, 2014), using the ATmega8535 microcontroller to control the Infusion pump, then in research(Nataliana et al., 2016)using the same microcontroller can monitor inpatient admissions by using infrared led sensor and Photodiode.

Furthermore, research on infusion monitoring is developing towards the internet of things (IOT) such as research(Sasmoko\& Wicaksono, 2017) using the Load Cell sensor and the Esp8266 Wi-Fi module can send information via the web of infusion droplets with an error margin of $2.4 \%$ data transmission. Furthermore(Yunardi et al., 2018) using telemetry technology and the LabVIEW application obtained a success rate of $96.7 \%$.

The use of smartphones for notification of infusion drops and monitoring was also carried out in research(Aziis, 2018). There was an error in the process of sending data and reading light sensors, in research(Yudhana\& Putra, 2018), monitoring using an Android smartphone had problems because communication using Bluetooth Hc-06 which maximum range of 10 meters. In a study (Anwar \& Ibadillah, 2018) Using a Photodiode and LED for droplet detection, and a Load Cell sensor for the remaining intravenous fluid, using the Esp8266 Wi-Fi module, error 0.59\%, remaining fluid 0.83\% within 30 seconds of delivery. Control device that utilizes internet technology by using social media telegram applications (Candra et al., 2019). Using NodeMCU ESP8266(Ilham et al., 2019). From previous research, it was inspired to design a Microcontroller Based Out of Infusion Warning Tool Design tool for patients using social media telegram as notification when the patient's infusion fluids will run out.(Candra\& Ilham, 2019).This research using Arduino Uno, sensor load cell, LED \&photodioda, ethernet shield daninterfaces by website(Maharani et al., 2019).(Suprayogi et al., 2019).(Wardani et 
al., 2018) design monitoring infuses using arduino and web have been acuration 95\%, LDR sensor $90 \%$ (Zufa, 2020) .

\section{LITERATURE REVIEW}

Intravenous therapy is placing a sterile fluid through a needle directly into the patient's vein. Usually sterile fluids contain electrolytes (sodium, calcium, potassium), nutrients, vitamins or drugs. Intravenous fluid's infusion is the administration of a certain amount of fluid into the body, through a needle, into a vein to replace lost fluids or nutrients from the body. Intravenous therapy is placing a sterile fluid through a needle directly into the patient's vein. Usually sterile fluids contain electrolytes (sodium, calcium, potassium), nutrients vitamins or drugs (Nur et al., 2015).

Inserting an IV is the insertion of fluids or drugs directly into the veins in large quantities and for a long time using an infusion set. Intravenous (IV) therapy is used to give fluids when the patient is unable to swallow, is unconscious, dehydrated or in shock, to deliver the salts needed to maintain the electrolyte balance, or glucose needed for metabolism and to administer medications.

\section{METHOD}

The tools and materials we use in designing a microcontroller based infusion warning device for patients consist of hardware and software, including:

\section{Hardware}

Equipment requirements used in the design of the input warning device include:

Table 1

Hardware Specifications

\begin{tabular}{|c|c|c|}
\hline No. & Name & Function \\
\hline 1 & Arduino Uno R3 & Controller in the design of the infusion warning device \\
\hline 2 & ESP8266 MCU & Connect the data generated by the microcontroller via the \\
\hline & Node Module & Telegram application \\
\hline 3 & HX711 module & $\begin{array}{l}\text { To program HX711, Arduino requires an additional } \\
\text { library, namely the } \mathrm{HX} 711 \text { library }\end{array}$ \\
\hline 4 & Load cell sensor & $\begin{array}{l}\text { The load cell sensor consists of } 4 \text { connectors connected to } \\
\text { the HX711 module which functions as a weight detector } \\
\text { for the infusion. }\end{array}$ \\
\hline 5 & Buzzer & $\begin{array}{l}\text { Buzzer circuit or what is often called a series of alarm } \\
\text { message reminders and alerts, }\end{array}$ \\
\hline 6 & Jumper & Connect the whole tool. \\
\hline 8 & NPN transistor & amplifier, controller, rectifier, oscillator, modulator \\
\hline
\end{tabular}

\section{Software}

The software used in designing a microcontroller based out infusion warning is:

Table 2

Software Requirements

\begin{tabular}{lll}
\hline No. & \multicolumn{1}{c}{ Name } & \multicolumn{1}{c}{ Function } \\
\hline 1 & Arduino IDE & $\begin{array}{l}\text { Used to upload a low infusion warning program to the } \\
\text { Arduino board. }\end{array}$ \\
2 & Proteus & Used to simulate circuits \\
3 & Fritzing & Used to design circuit schematics and electronics \\
4 & Microsoft Visio & Used for designing drawings, schematics \\
\hline
\end{tabular}




\section{Work procedures}

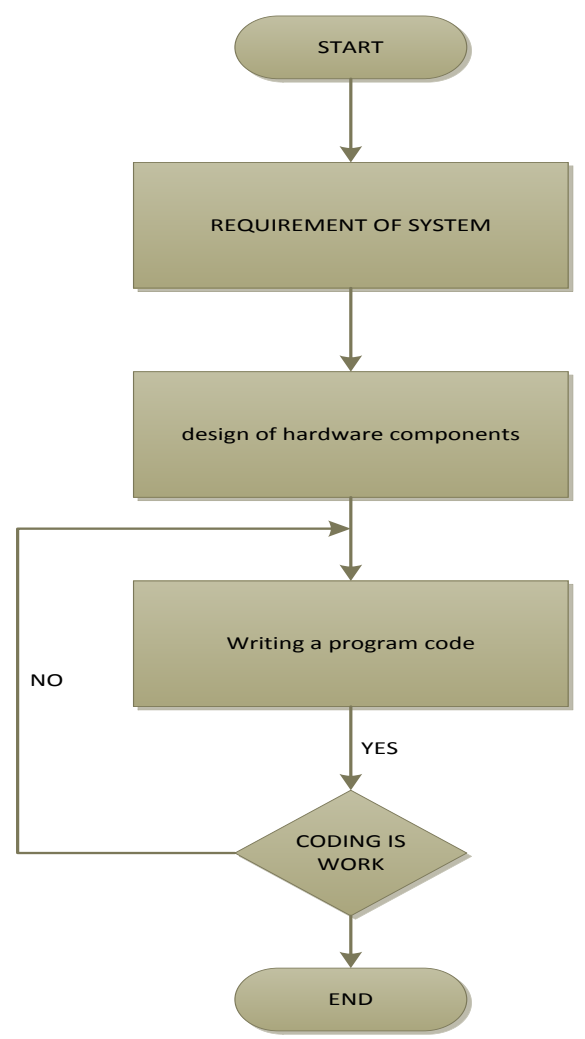

Figure 1. Work Procedure

\section{System planning}

This design is made to simplify the process of designing an infusion warning device using a microcontrollerbased load cell sensor. This series of out-of-infusion warning devices consists of 3 parts, namely the input section, the control section, the output section, shown in Figure 2.

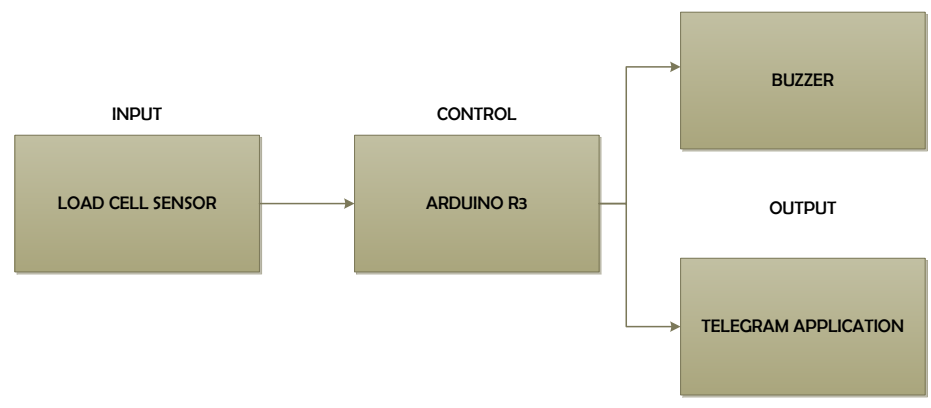

Figure 2. System Design

From Figure 2 it can be seen that there are 3 parts of the circuit, namely the input section, this section consists of a load cell sensor which functions to provide input values at the level of weight intensity that determines the condition of the infusion.

The control part, the infusion warning system control system uses Arduino which functions to receive input from the load cell sensor then gives commands to the HX711 module which is the translator converting the measured changes in resistance changes and converting them into voltage and weight quantities through the existing circuit, and then Hx711 tells the Wi-Fi module NodeMCU that I have to replace the weight of the IV, and then the output is sent to the telegram and buzzer.

The output section, which is the last result of this series of infusion warning tools, has two outputs, namely to the telegram application in the form of a message that the infusion is running low and must be replaced. And the other output is a buzzer, which is a sound that is issued, if the nurse does not replace the infusion if it has been warned 3 times via telegram earlier. 


\section{Working Principles of Tools}

The following is a flowchart of a design for how the infusion warning device will work.In Figure 3, there is a series of Flowchart programs for warning the infusion to run out for microcontrollerbased patients where the program starts from the start then the source will be installed by a load cell sensor, a program that will detect the weight of the infusion, and if the weight of the infusion has reached $137 \mathrm{~g}-140 \mathrm{~g}$.

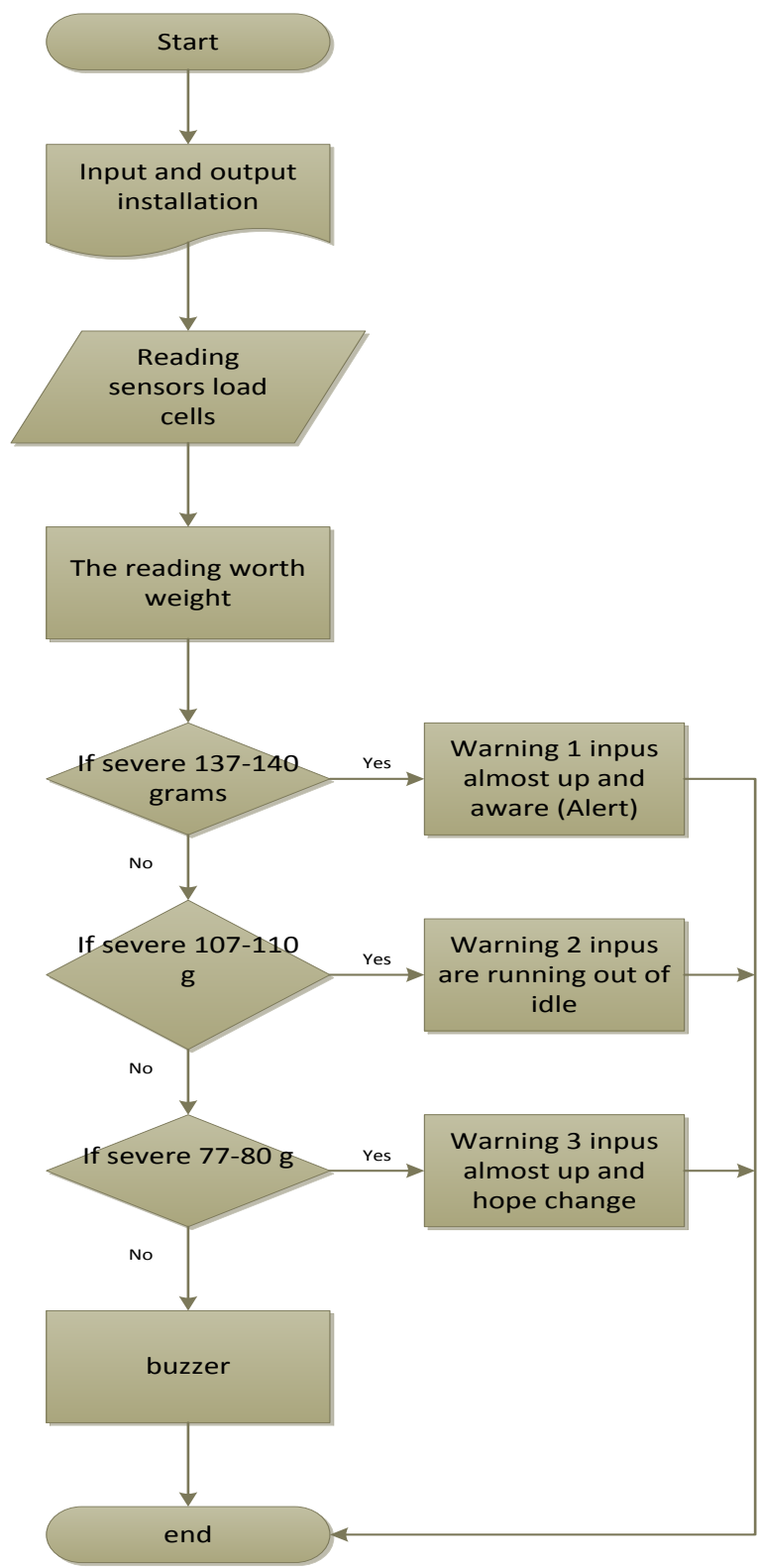

Figure 3 The working principle of the tool

It will be notifiedto nurses via a telegram application in the form of a message, to immediately replace a new infusion. And if the nurse does not replace the new infusion, a second warning will be given if the weight of the infusion has reached $107-110 \mathrm{~g}$, and the last if not replaced will be warned with a third warning when the weight has reached $77-80 \mathrm{~g}$ and will also be reminded with a sound alarm.

\section{Set of tools}

By using the Fritzing application, the following tool designs are obtained, This out of infusion warning works based on the input load cell that will read the weight, and then the HX711 module will process the data, and then notified to the NodeMCUESP8266 and controlled by Arduino, which then the Node MCU given notification via telegram application and buzzer. 


\section{Sin Sinkron : Jurnal dan Penelitian Teknik Informatika

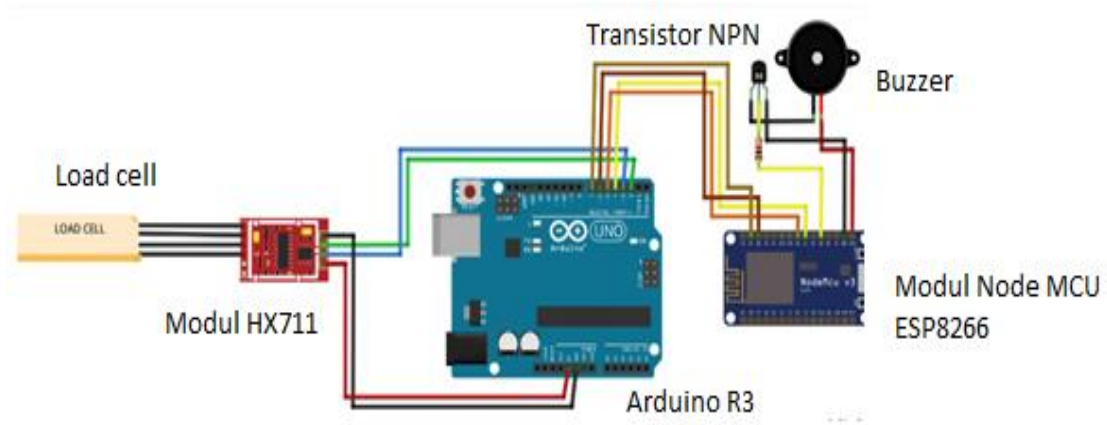

Figure 4 Schematic of the Tool

\section{Telegram Bot}

The author needs to make a bot on telegram so that the Load cell sensor can send notifications to telegram. Creating an author's telegram bot requires an author-able user token that can be accounted for @BotFather and a User ID that the author gets from the @ get_id account.

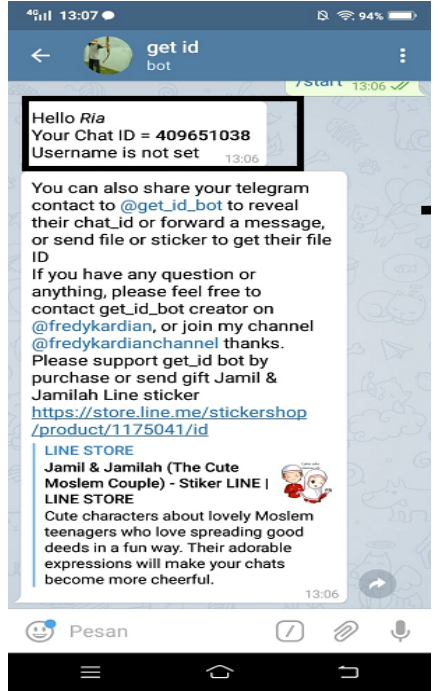

(a)Token Telegram

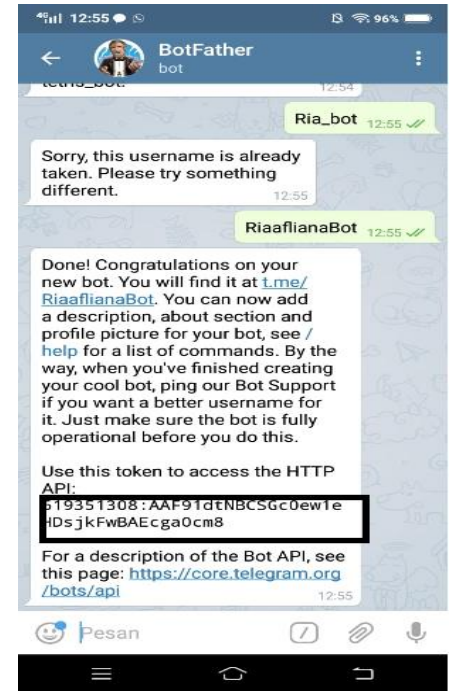

(b)User ID

Figure 5 (a) and (b) Design BOT Telegram

\section{RESULT}

The microcontroller based infusion warning works where the infusion that is input will be received by Arduino as the system controller, giving commands to the HX711 module as a liaison between Arduino and the Wi-Fi Node MCU module with output in the form of messages telegram and Buzzer.

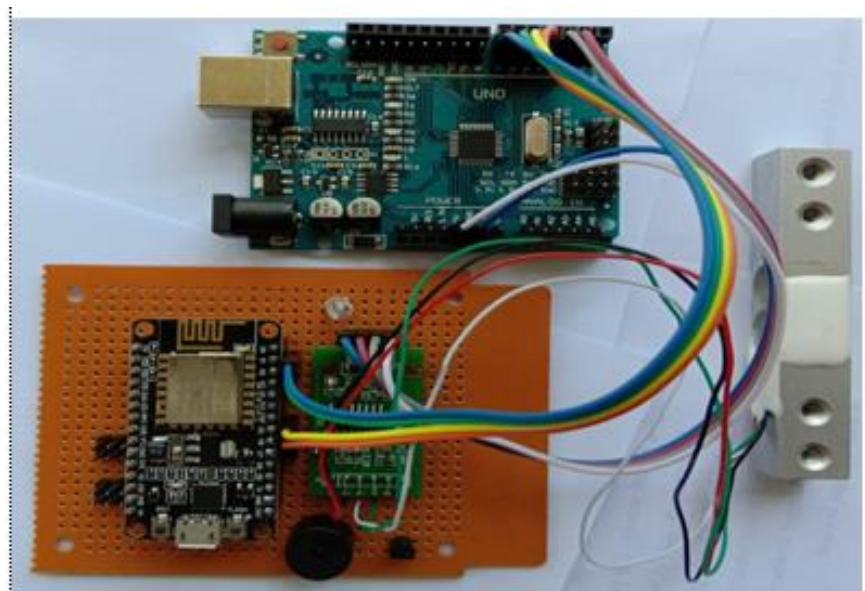

Figure 6. Overall Toolkit 


\section{Testing Procedure}

\section{Overall Tool Testing}

To run the microcontroller-based out infusion warning tool, it is as follows:

a) The first thing to do is to first assemble all the tools together and ready to run

b) After everything is connected, place the infusion in the load cell sensor which is the main input source.

c) After the load cell reads the weight of the infusion, the weight will be converted into analog data by the HX711 Module.

d) Then if the data has become in the form of digital data and controlled by Arduino, telegram and buzzer will be sent via the NodeMCUESP8266.

\section{Test result}

\section{Telegram}

When the status of the infusion on the serial monitor says normal (> 180g), the infusion is still a lot, and when the status changes to alert, the notification automatically enters the kettle, as we can see in Figure 4.And likewise if the status on the serial monitor has changed to standby, it will be automatically notified again that the infusion is standby. And when the infusion is running low on the serial monitor, it will send a notification to the telegram automatically as well, and when the infusion is in, please replace it, delay 7 seconds until the buzzer sounds 10 seconds continues to finish.

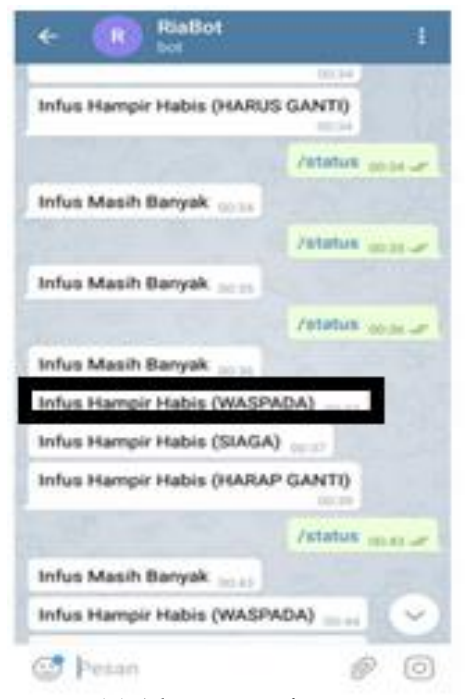

(a)Alert Warning

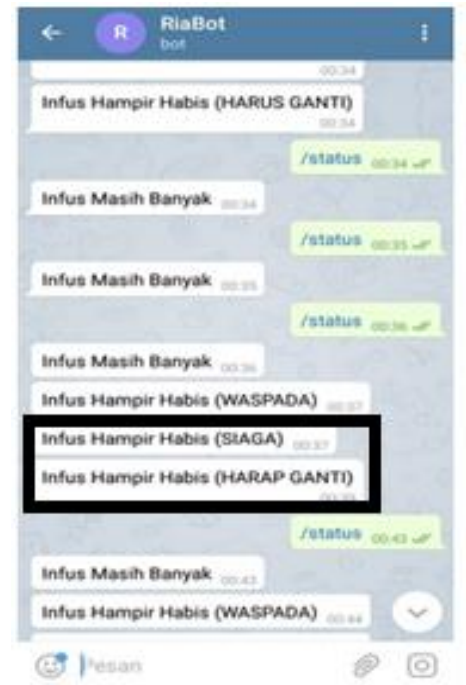

(b)Idle Warning

Figure 7.(a) and (b) Notification Via Telegram

Table 3

InfusionTest Data

\begin{tabular}{clcc}
\hline Test & \multicolumn{1}{c}{ Infusion status } & Notification (Y / N) & Time (S) \\
\hline 1 & The infusion is still a lot $(>190 \mathrm{~g})$ & $\mathrm{Y}$ & 3 seconds \\
& The infusion is running low (Alert) & $\mathrm{Y}$ & 4 seconds \\
& The infusion is low (standby) & $\mathrm{Y}$ & 3 seconds \\
& The infusion is low (please change) & $\mathrm{Y}$ & 2 seconds \\
2 & The infusion is still a lot (>189g) & $\mathrm{Y}$ & 3 seconds \\
& The infusion is running low (Alert) & $\mathrm{Y}$ & 3 seconds \\
& The infusion is low (standby) & $\mathrm{Y}$ & 5 seconds \\
& The infusion is low (please change) & $\mathrm{Y}$ & 3 seconds \\
3 & The infusion is still a lot (>187g) & $\mathrm{Y}$ & 3 seconds \\
& The infusion is running low (Alert) & $\mathrm{Y}$ & 4 seconds \\
& The infusion is low (standby) & $\mathrm{Y}$ & 4 seconds \\
& The infusion is low (please change) & $\mathrm{Y}$ & 3 seconds \\
4 & The infusion is still a lot (> 180g) & $\mathrm{Y}$ & 4 seconds \\
& The infusion is running low (Alert) & $\mathrm{Y}$ & 4 seconds \\
& The infusion is low (standby) & $\mathrm{Y}$ & 1 second \\
& The infusion is low (please change) & $\mathrm{Y}$ & 2 seconds \\
\hline
\end{tabular}


From table 3shows the results of the telegram notification test that the message that enters the telegram is successful when the load cell reads heavily until it sends a notification to the telegram, and can function as desired. The system used must be connected to an internet Network, the data transmission process depends on the signal strength of the hotspot or Wi-Fi.If the sensor has read the weight of $94 \mathrm{~g}$, the status will change to standby and the weight shown in the monitor serial is also in accordance with the factual situation, as we can see in Figure 8 which shows the weight read by the load cell sensor. The Node MCU monitor serial which is shown if the weight is $94 \mathrm{~g}$ will indicate an alert status, so this test proves that the output generated by the load cell is appropriate, as we can see in Figure 8.

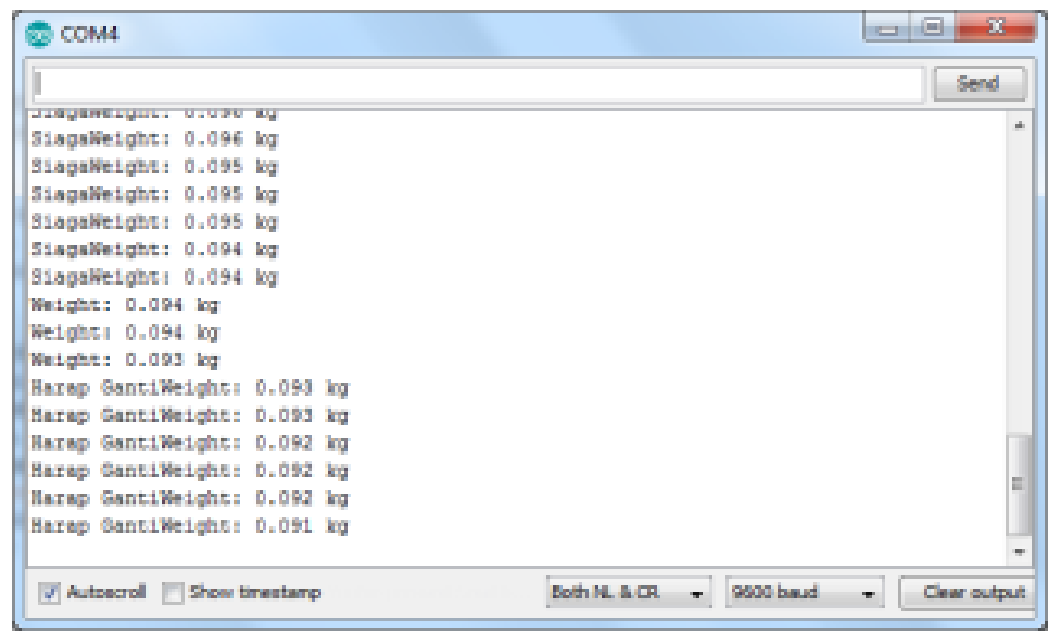

Figure 8. Testing Tools on Serial Monitor

\begin{tabular}{lcccc}
\hline No & Factual Weight & System Weight & Error & VAverage $^{2}$ \\
\hline 1 & $53 \mathrm{~g}$ & $53 \mathrm{~g}$ & 0 & 0 \\
2 & $181 \mathrm{~g}$ & $181 \mathrm{~g}$ & 0 & 0 \\
3 & $81 \mathrm{~g}$ & $81 \mathrm{~g}$ & 0 & 0 \\
4 & $129 \mathrm{~g}$ & $129 \mathrm{~g}$ & 0 & 0 \\
5 & $37 \mathrm{~g}$ & $37 \mathrm{~g}$ & 0 & 0 \\
6 & $22 \mathrm{~g}$ & $22 \mathrm{~g}$ & 0 & 0 \\
7 & $177 \mathrm{~g}$ & $177 \mathrm{~g}$ & 0 & 0 \\
8 & $103 \mathrm{~g}$ & $103 \mathrm{~g}$ & 0 & 0 \\
9 & $80 \mathrm{~g}$ & $80 \mathrm{~g}$ & 0 & 0 \\
10 & $43 \mathrm{~g}$ & $43 \mathrm{~g}$ & 0 & 0 \\
11 & $14 \mathrm{~g}$ & $14 \mathrm{~g}$ & 0 & 0 \\
12 & $16 \mathrm{~g}$ & $16 \mathrm{~g}$ & 0 & 0 \\
13 & $82 \mathrm{~g}$ & $82 \mathrm{~g}$ & 0 & 0 \\
14 & $21 \mathrm{~g}$ & $21 \mathrm{~g}$ & 0 & 0 \\
15 & $15 \mathrm{~g}$ & $15 \mathrm{~g}$ & 0 & 0 \\
16 & $57 \mathrm{~g}$ & $57 \mathrm{~g}$ & 0 & 0 \\
17 & $16 \mathrm{~g}$ & $16 \mathrm{~g}$ & 0 & 0 \\
18 & $47 \mathrm{~g}$ & $47 \mathrm{~g}$ & 0 & 0 \\
19 & $17 \mathrm{~g}$ & $17 \mathrm{~g}$ & 0 & 0 \\
20 & $6 \mathrm{~g}$ & $6 \mathrm{~g}$ & 0 & 0 \\
21 & $17 \mathrm{~g}$ & $17 \mathrm{~g}$ & 0 & 0 \\
22 & $21 \mathrm{~g}$ & $21 \mathrm{~g}$ & 0 & 0 \\
23 & $12 \mathrm{~g}$ & $12 \mathrm{~g}$ & 0 & 0 \\
24 & $31 \mathrm{~g}$ & $31 \mathrm{~g}$ & 0 & 0 \\
25 & $199 \mathrm{~g}$ & $199 \mathrm{~g}$ & 0 & 0 \\
26 & $61 \mathrm{~g}$ & $61 \mathrm{~g}$ & 0 & 0 \\
27 & $61 \mathrm{~g}$ & $61 \mathrm{~g}$ & 0 & 0 \\
28 & $188 \mathrm{~g}$ & $188 \mathrm{~g}$ & 0 & 0 \\
29 & $79 \mathrm{~g}$ & $79 \mathrm{~g}$ & 0 & 0 \\
30 & $160 \mathrm{~g}$ & $160 \mathrm{~g}$ & 0 & 0 \\
31 & $11 \mathrm{~g}$ & $111 \mathrm{~g}$ & 0 & 0 \\
32 & $102 \mathrm{~g}$ & $102 \mathrm{~g}$ & 0 & 0 \\
33 & $85 \mathrm{~g}$ & $85 \mathrm{~g}$ & 0 & \\
\hline & & & & 0 \\
\hline
\end{tabular}




\begin{tabular}{lcccc}
\hline 34 & $39 \mathrm{~g}$ & $39 \mathrm{~g}$ & 0 & 0 \\
35 & $84 \mathrm{~g}$ & $84 \mathrm{~g}$ & 0 & 0 \\
36 & $4 \mathrm{~g}$ & $4 \mathrm{~g}$ & 0 & 0 \\
37 & $61 \mathrm{~g}$ & $61 \mathrm{~g}$ & 0 & 0 \\
38 & $45 \mathrm{~g}$ & $45 \mathrm{~g}$ & 0 & 0 \\
39 & $9 \mathrm{~g}$ & $9 \mathrm{~g}$ & 0 & 0 \\
40 & $15 \mathrm{~g}$ & $15 \mathrm{~g}$ & 0 & 0 \\
& & & & $\sum \sqrt{ } \mathrm{x}^{2}=0$ \\
\hline
\end{tabular}

\section{DISCUSSION}

Verification testing is done by comparing the results of factual weight and system weight, using the Means Square Error (MSE) formula. Test one shows a weight of 53g in factual status and shows a please change status in the system status, indicating that the load cell sensor has successfully read the load. Meanwhile, the second test has the factual weight of $181 \mathrm{~g}$ and shows that it is in a normal system status, because the weight read by the load cell is the same as the factual weight, which means that the system verification test stage is successful, and so on. So valueMean Square Error (MSE) is 0 .

$$
\begin{aligned}
& \text { MSE }=\sum \sqrt{\left(\frac{\text { Factual- SISTEM }}{n}\right)^{2}} \\
& =\frac{0}{40} \\
& =0
\end{aligned}
$$

\section{CONCLUSION}

Based on the test results on the out-of-use infusion warning device for microcontroller-based patients, several conclusions can be drawn:

The device will send a notification via telegram, when the remaining weight of the intravenous fluid is $137 \mathrm{~g}$ to $140 \mathrm{~g}, 107 \mathrm{~g}$ to $110 \mathrm{~g}$, and $77 \mathrm{~g}$ to $80 \mathrm{~g}$. Messages sent by telegram were sent 3 times, namely a WARNING the infusion was running low (Alert), a WARNING the infusion was running low (Standby) and a WARNING the infusion was running low (Please replace it). If not replaced by the nurse, they will be ranked with a Buzzer. From the verification test of the weight of the infusion, the MSE is 0.

\section{REFERENCES}

Anwar, H. N., \& Ibadillah, A. F. (2018). Alat Pemantau Kondisi Infus Dengan Internet Of Things (IoT) Berbasis Mikrokontroler ATmega16. Jurnal Teknik Elektro Dan Komputer TRIAC, 5(1), 1-5.

Aziis, M. S. (2018). Automatic Stoping and Infusion Monitoring With Telemetry System Based on Android. EJPTE (Jurnal Elektronik Pendidikan Teknik Elektronika), 7(3), 210.

Candra, R. A., \& Ilham, D. N. (2019). Analisis Efisiensi Energi Pada Aplikasi Media Sosial Menggunakan Perangkat Komunikasi Bergerak. 9, 125-131.

Candra, R. A., Ilham, D. N., Hardisal, H., \& Sriwahyuni, S. (2019). Light Control Design by Using Social Media Telegram Applications Based on Internet Of Things (IOT). SinkrOn, 3(2), 200. https://doi.org/10.33395/sinkron.v3i2.10094

Erdisna, E. (2014). Rancang Bangun Penghitung Tetesan, Pencegah Gelembung Udara, Dan Drip Chamber Pada Infus Pasien. MAJALAH ILMIAH UPI YPTK, 21(2).

Ilham, D. N., Hardisal, H., Balkhaya, B., Candra, R. A., \& Sipahutar, E. (2019). Heart Rate Monitoring and Stimulation with the Internet of Thing-Based (IoT) Alquran Recitation. SinkrOn, 4(1), 221. https://doi.org/10.33395/sinkron.v4i1.10392

Maharani, R., Muid, A., Ristian, U., Rekayasa, J., \& Komputer, S. (2019). Sistem Monitoring Dan Peringatan Pada Volume Cairan Intravena ( Infus ) Pasien Menggunakan. 07(03).

Nataliana, D., Taryana, N., \& Riandita, E. (2016). Alat Monitoring Infus Set pada Pasien Rawat Inap Berbasis Mikrokontroler ATmega 8535. ELKOMIKA: Jurnal Teknik Energi Elektrik, Teknik Telekomunikasi, \& Teknik Elektronika, 4(1), 1.

NUR, F. (2016). Perancangan dan pembuatan alat monitoring infus pada pasien dengan menggunakan jaringan wireless berbasis mikrokontroler. University of Muhammadiyah Malang.

Sasmoko, D., \& Wicaksono, Y. A. (2017). Implementasi Penerapan Internet Of Things (Iot) Pada Monitoring Infus Menggunakan Esp 8266 Dan Web Untuk Berbagi Data. Jurnal Ilmiah Informatika, 2(1), 90-98.

Suprayogi, H., Priyandoko, G., Studi, P., Elektro, T., Teknik, F., Malang, U. W., Studi, P., Informatika, T., Teknik, 
F., \& Malang, U. W. (2019). Pembuatan infus elektronik rumah sakit. 5068, $23-32$.

Wardani, C. K., Soelistianto, F. A., Taufik, M., Digital, J. T., \& Malang, P. N. (2018). Rancang Bangun Sistem Monitoring Tetes Siklus Periodik Infus. 29-35.

Yudhana, A., \& Putra, M. D. D. (2018). Rancang Bangun Sistem Pemantauan Infus Berbasis Android. Transmisi, 20(2), 91. https://doi.org/10.14710/transmisi.20.2.91-95

Yunardi, R. T., Setiawan, D., Maulina, F., \& Prijo, T. A. (2018). Pengembangan Sistem Kontrol dan Pemantauan Tetesan Cairan Infus Otomatis Berbasis Labview dengan Logika Fuzzy. Jurnal Teknologi Informasi Dan Ilти Komputer, 5(4), 403-410.

Zufa, M. F. (2020). Perancangan Sistem Pemantauan Level Cairan Infus Menggunakan NodeMcU dan Sensor Photodioda Terintegrasi IoT (Internet Of Thing). 